\title{
Purification and Reconstitution of an Integral Membrane Protein, the Photoreaction Center of Rhodobacter sphaeroides, Using Synthetic Sugar Esters
}

BioTechniques 28:1214-1219 (June 2000)

\author{
H. Peters, C. Schmidt- \\ Dannert, L. Cao, U.T. \\ Bornscheuer and R.D. Schmid \\ University of Stuttgart, \\ Stuttgart, Germany
}

\begin{abstract}
Detergents are indispensable reagents for the extraction and solubilization of integral membrane proteins, but their removal from a reconstituted phospholipid-protein complex is usually desirable. In this paper, we describe a novel method in which the synthetic sugar esters 6-O-octanoyl- $\beta-D-$ glucose $(O G)$ or 6-O-octanoyl- $\beta$-D-mannose (OM) are used as detergents for both the isolation and the rapid reconstitution of the photosynthetic reaction center protein of Rhodobacter sphaeroides. Following solubilization of the reaction center with $O G$ or OM and reconstitution of this protein in liposomes, a convenient removal of these detergents was achieved within less than two hours by hydrolytic cleavage of the sugar esters using immobilized lipases. Best results were achieved with lipase from Bacillus sp. immobilized on silica gel.
\end{abstract}

\section{INTRODUCTION}

Before purification, lipid-associated integral membrane proteins must be separated from the lipid membrane components. This step, termed solubilization, is commonly achieved with amphiphilic, anionic or nonionic detergents such as $\mathrm{N}, \mathrm{N}$-dimethyldodecylamine $\quad \mathrm{N}$-oxide (LDAO), cholate, $n$-octyl- $\beta$-D-glucopyranoside (OGP), $\beta$-dodecyl-maltoside or Triton ${ }^{\circledR} \mathrm{X}-100(5,12,14,17)$. Detergents usually must be present during each purification step to maintain both protein solubility and functional activity but should be removed from the reconstituted proteoliposomes.

Nonionic detergents are often preferred over amphiphilic or anionic surfactants because they are less prone to denature proteins and do not interfere with purificaton steps involving ion-exchange chromatography. The nonionic surfactant OGP is particularily popular as a detergent for the solubilization of membrane proteins and their reconstitution in liposomes $(7,8,10,13,16,20)$. OGP has a high critical micellar concentration (CMC) $(23.3 \mathrm{mM})$ and thus can be removed by dialysis $(18,25)$. However, a substantial reduction of surfactant may take up to $48 \mathrm{~h}$ (5), enough time for a protein to lose activity or undergo denaturation. If nonionic detergents of low CMC such as Triton X-100 (15) are used, the addition of BiobeadsSM2 (11) or Amberlite XAD-2 (19), both of which are commercially available, has proven a useful technique to remove trace levels of surfactants.

In the course of our studies on the synthesis of sugar fatty acid esters by li- pase catalysis, we have recently synthesized 6- $O$-octanoyl- $\beta$-D-glucose (OG) and 6-O-octanoyl- $\beta$-D-mannose $(\mathrm{OM})$ $(1,2)$, which match the surfactant properties of OGP but have advantages for the purification of membrane proteins. Thus, unlike OGP, OG and OM can both be hydrolyzed in a lipase-catalyzed reaction, leaving the phospholipids within the liposomes unaffected. We describe here the application of this technique for the rapid purification and reconstitution of the photosynthetic reaction center protein from Rhodobacter sphaeroides.

\section{MATERIALS AND METHODS}

\section{Materials}

1,2-Dimyristoyl-sn-glycero-3-phosphocholine (DMPC), 1,2-dipalmitoylsn-glycero-3-phosphocholine (DPPC) and LDAO were purchased from Fluka Chemie (Buchs, Switzerland). OGP was purchased from Sigma (St. Louis, MO, USA), and silica gel was purchased from Merck (Darmstadt, Germany). OG and $\mathrm{OM}$ were synthesized as previously described (4). Lipase from Bacillus sp. was obtained from Asahi Chemicals (Tokyo, Japan), and lipase from Candida rugosa was purchased from Biocatalyst (Pontybridd, UK). Immobilized lipases from $C$. antarctica (CAL-B = SP435, CAL-A/B = SP382) and from Rhizomucor miehei (Lipozyme) were gifts from Novo Nordisk (Bagsvaerd, Denmark) and Roche Diagnostics (Penzberg, Germany). All other chemicals were from common suppliers and obtained at the highest purity available. 


\section{Cultivation of $R$. sphaeroides}

R. sphaeroides DSM 158 was cultivated in 1-L shaking flasks in a medium described by Sistrom (21). To obtain anaerobic conditions, cultures were aerated with nitrogen and cultivated in darkness for $16 \mathrm{~h}$ before illumination with 1300 lux for three days. Cells were harvested in the late log phase by centrifugation $\left(11000 \times g\right.$ at $\left.4^{\circ} \mathrm{C}\right)$ and frozen at $-20^{\circ} \mathrm{C}$ for storage or directly used for isolation and purification of the photoreaction center protein.

\section{Extraction and Purification of the Reaction Center Protein}

$R$. sphaeroides cells (100 g) were suspended in $200 \mathrm{~mL} 20 \mathrm{mM}$ Tris- $\mathrm{HCl}$ (pH 8.0) containing $10 \mathrm{mg}$ lysozyme and DNase. The suspension was stirred for $45 \mathrm{~min}$ in darkness at room temperature. Following sonification of the suspension for $60 \mathrm{~min}$ on ice, the debris was removed from the preparation by low-spin centrifugation at $20000 \times g$ for $30 \mathrm{~min}$ at $4^{\circ} \mathrm{C}$. Chromatophores in the supernatant were collected by ultracentrifugation at $200000 \times g$ for $2 \mathrm{~h}$ at $4^{\circ} \mathrm{C}$. Extraction of the reaction center protein from the chromatophores was performed by diluting the chromatophores to $A_{850}=1[850 \mathrm{~nm}=$ Qy-band of special pair, bacteriochlorophyll dimer (23) with $20 \mathrm{mM}$ Tris- $\mathrm{HCl}$ (pH 8.0), 50 $\mathrm{mM} \mathrm{NaCl}, 0.5 \mathrm{mM}$ PMSF containing either $8 \mathrm{mg} / \mathrm{mL}$ sugar esters (OG or $\mathrm{OM}$ ) or $0.25 \%(\mathrm{v} / \mathrm{v}) \mathrm{LDAO}$, followed by agitation for $1 \mathrm{~h}$ at room temperature]. The solubilized reaction center protein was separated from chromatophores by ultracentrifugation at $200000 \times g$ for $2 \mathrm{~h}$ at $4^{\circ} \mathrm{C}$. The chromatophores were then extracted a second time.

Purification of the solubilized reaction center protein was carried out as previously described (16) by ion exchange chromatography using S- and Q-Sepharose ${ }^{\circledR}$ columns sequentially. The columns $(30 \times 2 \mathrm{~cm})$ were equilibrated with $20 \mathrm{mM}$ Tris- $\mathrm{HCl}(\mathrm{pH} 8.0)$ containing $8 \mathrm{mg} / \mathrm{mL}$ sugar ester or $0.25 \%$ LDAO (v/v), respectively. The extracted reaction center protein was loaded on the S-Sepharose column with $250 \mathrm{~mL}$ equilibration buffer (flow rate of $4 \mathrm{~mL} / \mathrm{min}$ ) and was retained on the
Q-Sepharose column. After disconnection of the S-Sepharose column, the reaction center protein was eluted from the Q-Sepharose column with a gradient of $0.125-1 \mathrm{M} \mathrm{NaCl}$ in equilibration buffer. The reaction center protein containing fractions were pooled, concentrated by ultrafiltration and finally dialyzed against equilibration buffer.

The purity of the reaction center protein was estimated by SDS-PAGE, followed by staining with Coomassie Blue $^{\circledR}$. The reaction center protein concentration was determined spectrophotometrically at $802 \mathrm{~nm}(\varepsilon=288 \mathrm{mM} /$ cm) (22). The absorbance ratio $\mathrm{A}_{280} /$ $\mathrm{A}_{802}$ was routinely used for quantification of purity. Protein concentrations were determined with bicinchoninic acid, using the BCA Protein Detection Kit from Pierce Chemical (Rockford, IL, USA).

\section{Immobilization of Lipases}

Immobilization of lipases on activated silica gel was performed according to a modified method from Weetal (24) or on anion exchange resins QSepharose or $n$-octyl-Sepharose as described elsewhere (3).

\section{Hydrolysis of Sugar Fatty Acid Esters}

Immobilized lipases (100 mg) ( $B a-$ cillus sp. or C. rugosa) or $20 \mathrm{mg}$ commercially available immobilized lipases (CAL-B, CAL-A/B or RML) were added to $1 \mathrm{~mL} 50 \mathrm{mM}$ Tris-HCl buffer (pH 8.0) containing 9.2 mg OG. The reaction mixture was incubated at $40^{\circ} \mathrm{C}$, and $100-\mu \mathrm{L}$ aliquots were withdrawn at intervals of $1 \mathrm{~h}$ and analyzed by TLC and HPLC (data not shown).

\section{Lipase Method for Reconstitution}

DMPC $(1 \mathrm{mg} / \mathrm{mL})$ was solubilized with $8 \mathrm{mg} / \mathrm{mL}$ OGP in $100 \mathrm{mM}$ Tris$\mathrm{HCl}(\mathrm{pH} 8.0)$. Then, the purified reaction center protein solubilized in OG (final molar ratio of protein:lipid of 1:1000) and $20 \mathrm{mg} / \mathrm{mL}$ immobilized lipase were added, and the mixed micellar solution was incubated at $40^{\circ} \mathrm{C}$ for $0.5-1 \mathrm{~h}$. The immobilized matrix was separated from the liposome solution by short centrifugation or filtration.

\section{Analytical Methods}

TLC analysis was performed on nonactivated silica gel plates using ethylacetate:methanol:water $(80: 20: 5)$ as the developing system and $\mathrm{OG}$ as a standard. The plates were sprayed with $50 \%(\mathrm{v} / \mathrm{v})$ sulfuric acid and heated at $110^{\circ} \mathrm{C}$ for $5 \mathrm{~min}$ to develop the sugar and sugar ester spots.

Quantitative analysis of OG conversion was carried out on an HPLC system (Sykam, Gilching, Germany) equipped with a Nucleosil $120-5 \mathrm{C}_{18}$ column (Crom, Herrenberg, Germany) and a light-scattering detector. Chromatography was performed with methanol:acetonitrile:water (50:30:20) as the mobile phase and a flow rate of $1 \mathrm{~mL} /$ $\min$ at $40^{\circ} \mathrm{C}$.

The integrity of liposomal phospholipids after lipase treatment was checked by HPLC by extracting the lipid components from the reaction mixture using chloroform:methanol $(2: 1)$ followed by washing steps with sodium bicarbonate and water. Analysis was carried out on a $250 \times 4$-mm I.D. column (Macherey-Nagel GmbH, Düren, Germany) packed with $5 \mu \mathrm{m}$ unmodified Nucleosil. Elution (flow rate of 1 $\mathrm{mL} / \mathrm{min}$ ) was performed in gradient mode (starting with $100 \% \mathrm{~A}$ and decreasing over $20 \mathrm{~min}$ to $100 \% \mathrm{~B}$ ) with solvent A = isopropanol:isohexane (4:3) and solvent $\mathrm{B}=$ isopropanol:isohexane:water (8:6:1.5).

\section{Characterization of Liposomes}

Light-scattering measurements of liposomes, diluted with the corresponding buffer to a final phospholipid concentration of $1 \mathrm{mg} / \mathrm{mL}$, were carried out with a Zetasizer 3 particle analyzer (Malvern Instruments, Malvern, UK). The distribution of particle sizes was measured in the range of $3 \mathrm{~nm}-6.54$ $\mu \mathrm{m}$ using dynamic light scattering.

\section{RESULTS}

\section{Solubilization and Purification of Reaction Center Protein}

The reaction center protein was efficiently extracted from the chromatophores with both OG or OM (Table 1). 
Yields of the protein were similar if either LDAO or OG was used, but dropped to half if extractions were based on OM. However, the purification factor using $\mathrm{OM}$ was about 5.5 times higher as compared to the LDAO extractions.

Extracts containing the protein, solubilized with either one of the three detergents, were further purified by ion exchange chromatography, maintaining the same detergent concentrations used for extraction throughout the entire chromatographic procedure. Instead of the three chromatographic steps used in the protocol of Gray et al. (9), we developed a single-step purification using $\mathrm{S}$ - and Q-Sepharose columns in sequence. While the reaction center protein was retained on the Q-Sepharose column at $\mathrm{pH} 8.0$, most other proteins either passed through both columns unbound or bound firmly to the SSepharose column. By detaching the SSepharose column, the protein could be eluted from the Q-Sepharose column using a $\mathrm{NaCl}$ gradient from $0.125-1 \mathrm{M}$. Elution of the protein started at $0.4 \mathrm{M}$ $\mathrm{NaCl}$, whether or not LDAO or sugar esters were used during the chromatography. The protein-containing fractions were pooled and analyzed (Table 1). In the case of LDAO and OG, about $80 \%$ of the protein applied to the ion exchange columns was finally eluted from the Q-Sepharose column, while in the case of OM, a somewhat lower yield of about $70 \%$ was obtained.

The purity of the reaction center protein solubilized and purified by means of the sugar esters was higher (1.7 or 1.9) (Figure 1) compared to the values obtained using LDAO (1.2) as the detergent (Table 1).

\section{Hydrolysis of Sugar Fatty Acid Esters with Immobilized Lipases}

To achieve reconstitution of pure reaction center protein, the detergent must be removed during proteoliposome formation. Because both OG and OM were synthesized by lipase-catalyzed esterification, it was likely that lipase-catalyzed hydrolysis of these esters should allow for the complete hydrolysis of these surfactants. The use of lipases in an immobilized form should further ensure a simple removal of the

Table 1. Isolation and Purification of the Photosynthetic Reaction Center Protein from $R$. sphaeroides with $8 \mathrm{mg} / \mathrm{mL}$ Synthetic Sugar Esters OG or OM or $0.25 \%$ (v/v) LDAO

\begin{tabular}{|lcc|}
\hline $\begin{array}{l}\text { Purification } \\
\text { step }\end{array}$ & $\begin{array}{c}\text { Yield } \\
(\mathbf{\%})\end{array}$ & $\begin{array}{c}\text { Purification ratio } \\
\left(\mathbf{A}_{\mathbf{2 8 0}} / \mathbf{A}_{\mathbf{8 0 2}}\right)\end{array}$ \\
\hline Cell disruption & 100 & 20 \\
Chromatophores & 47 & 3.1 \\
Extractions & & \\
LDAO & 14.8 & 1.7 \\
OG & 12.9 & 2.4 \\
OM & 7.6 & 7.6 \\
lon exchange & & \\
chromatography & 11.8 & 1.2 \\
LDAO & 10.2 & 1.7 \\
OG & 5.2 & 1.9 \\
OM & & \\
\hline
\end{tabular}

biocatalyst after completion of the reaction. Hence, commercial lipases from either C. rugosa or Bacillus sp. were covalently immobilized on activated silica gel, and $C$. rugosa was also immobilized on n-octyl- and QSepharose. In addition, commercial immobilized lipases from $R$. miehei (Lipozyme) and C. antarctica (CAL-B, CAL-A/B) were investigated. Since $\mathrm{OG}$, when compared to OM, led to somewhat higher yields of reaction center protein after extraction and purification, hydrolysis of $\mathrm{OG}$ was chosen as the model reaction for the selection of an appropriate immobilized biocatalyst. After $2 \mathrm{~h}$ of incubation, greater than $60 \%$ of the sugar ester was hydrolyzed with all immobilized lipase preparations, except for C. rugosa immobilized on Q-Sepharose. Complete hydrolysis after $2 \mathrm{~h}$ of incubation was obtained only with $C$. rugosa immobilized on $n$-octyl-Sepharose and with Bacillus sp. immobilized on silica gel (Table 2).

\section{Liposome Preparation by Hydrolysis of Sugar Fatty Esters}

For liposome preparation, a mixture consisting of the commercially available DMPC $(1 \mathrm{mg} / \mathrm{mL})$ solubilized with either OG or OM $(8 \mathrm{mg} / \mathrm{mL})$ and immobilized lipase $(100 \mathrm{mg} / \mathrm{mL})$ in $100 \mathrm{mM}$ Tris- $\mathrm{HCl}$ (pH 8.0) was incubated for $2 \mathrm{~h}$ at $40^{\circ} \mathrm{C}$. Liposomes were then separated by a brief centrifugation or filtration step, which worked well if silica was used as an immobilization matrix, but failed with lipases immobilized on other matrices, possibly because of liposome adsorption. Bacillus sp. immobilized on activated silica gel $(100 \mathrm{mg} / \mathrm{mL})$ allowed for the most rapid hydrolysis of sugar esters without interference with liposome formation and thus was chosen for all subsequent experiments.

After $2 \mathrm{~h}$ of incubation, the sugar esters used for the solubilization of DMPC were completely hydrolyzed by immobilized Bacillus sp., as verified by TLC. Octanoic acid has a solubility of about $7 \mathrm{~g} / \mathrm{L}$, and glucose is infinitely soluble in water. As the initial concentration of $\mathrm{OG}$ or $\mathrm{OM}$ is $8 \mathrm{~g} / \mathrm{L}$, we

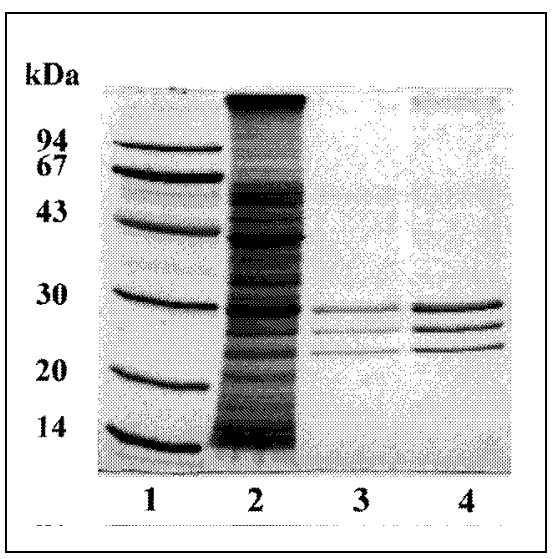

Figure 1. SDS-PAGE of solubilized and purified reaction center protein after ion-exchange chromatography. Lane 1: low molecular weight marker, lane 2: solubilized protein with OG, lane 3: purified protein in the presence of OM, lane 4: purified protein in the presence of OG. The protein is composed of three subunits $\mathrm{M}(30.7 \mathrm{kDa})$, $\mathrm{H}(28.1 \mathrm{kDa})$ and L (26.0 kDa). 
Table 2. Hydrolysis of OG with Immobilized Lipases

\begin{tabular}{|c|c|c|c|c|}
\hline \multirow[b]{2}{*}{ Lipase } & \multirow[b]{2}{*}{ Carrier for Immobilization } & \multicolumn{3}{|c|}{ Conversion (\%) } \\
\hline & & $1 \mathrm{~h}$ & $2 \mathrm{~h}$ & $3 \mathrm{~h}$ \\
\hline CRLa & $n$-octyl-Sepharose & 85 & 100 & - \\
\hline CRLa & Q-Sepharose & 3 & 7 & 10 \\
\hline$C R L^{a}$ & Silica & 40 & 75 & 90 \\
\hline $\mathrm{BSL}^{\mathrm{a}}$ & Silica & 80 & 100 & - \\
\hline $\mathrm{CAL}-\mathrm{B}^{\mathrm{b}}$ & Polyacrylic resin & 38 & 77 & 80 \\
\hline $\mathrm{CAL}-\mathrm{A} / \mathrm{B}^{\mathrm{b}}$ & Polyacrylic resin & 30 & 62 & 76 \\
\hline RMLb & Duolite 568 & 47 & 60 & 74 \\
\hline \multicolumn{5}{|c|}{$\begin{array}{l}\text { Addition of a } 100 \mathrm{mg} / \mathrm{mL} \text { wet immobilized or b20 mg/mL dry immobilized lipase. } \\
\text { Reaction conditions: } 9.2 \mathrm{mg} / \mathrm{mL} \text { OG in } 100 \mathrm{mM} \text { Tris- } \mathrm{HCl}(\mathrm{pH} 8.0) \text { at } 40^{\circ} \mathrm{C} \text {. } \\
\text { CRL, C. rugosa; BSL, Bacillus sp.; RML, R. miehei. }\end{array}$} \\
\hline
\end{tabular}

presume in the absence of experimental evidence that glucose has dissolved completely in the aqueous phase and trace octanoic acid may have remained in the liposomes. DMPC, the phospholipid used for liposome formation, did not react with BSL, as confirmed by HPLC analysis.
The liposomes, spontaneously formed after hydrolysis of the sugar esters, were easily separated from the silica gel matrix by filtration or a short centrifugation step. Light-scattering measurements revealed the presence of rather large vesicles of 170-610 nm (OG) and 145-710 nm (OM) (Table 3). To obtain a narrower particle-size distribution, the suspension was extruded 10 times through a polycarbonate membrane with a pore diameter of 200 $\mathrm{nm}$. After this step, DMPC liposomes prepared by hydrolysis of either sugar ester became more uniform with a mean diameter of about $150 \mathrm{~nm}$, as confirmed by light-scattering measurements (Figure 2) and were similar to DMPC liposomes prepared by the conventional detergent dialysis method using OGP as a detergent (mean diameter of about $203 \mathrm{~nm}$ ) (data not shown).

Similar results were achieved when DMPC was replaced by DPPC. Again, 


\section{Research Report}

Table 3. Liposome Size as Determined by Light Scattering

\begin{tabular}{|cccc|}
\hline $\begin{array}{c}\text { Sugar } \\
\text { fatty ester }\end{array}$ & Phospholipid & $\begin{array}{c}\text { Extrusion } \\
\text { (200-nm pore diameter) }\end{array}$ & $\begin{array}{c}\text { Light } \\
\text { scattering }\end{array}$ \\
\hline \multirow{2}{*}{ OG } & DMPC & - & $110-850$ \\
& DMPC & $10 \times$ & $110-280$ \\
& DMPC + RC & $10 \times$ & $130-225$ \\
& DPPC & $10 \times$ & $145-210$ \\
OM & DMPC & - & $120-810$ \\
& DMPC & $10 \times$ & $118-221$ \\
& DMPC + RC & $10 \times$ & $165-197$ \\
RC, reaction center protein. & $10 \times$ & $135-168$ \\
& DPPC & & \\
\end{tabular}

spontaneous formation of DPPC liposomes occured after $2 \mathrm{~h}$ of incubation, and a homogenous liposome population with a mean diameter of $150 \mathrm{~nm}$ formed after extrusion (Table 3 ). In addition, we found that Bacillus sp. could be reused 10 times without activity loss (data not shown).

\section{Reconstitution of Reaction Center Protein into Liposomes}

For our reconstitution experiments, reaction center protein, solubilized by
OG, was added to a mixture of DMPG/OG $(1: 8, w / w)$ to a final concentration of protein:DMPC of 1:1000, and immobilized lipase was added. After $2 \mathrm{~h}$, formation of large proteoliposomes with diameters of $700 \mathrm{~nm}$ was observed by light-scattering measurements. Again, extrusion led to a rather homogenous population of proteoliposomes with a mean diameter of $150 \mathrm{~nm}$ (Table 3). A continuous absorption spectrum in the range of 200-900 nm for these proteoliposomes showed a typical increase of absorption at lower

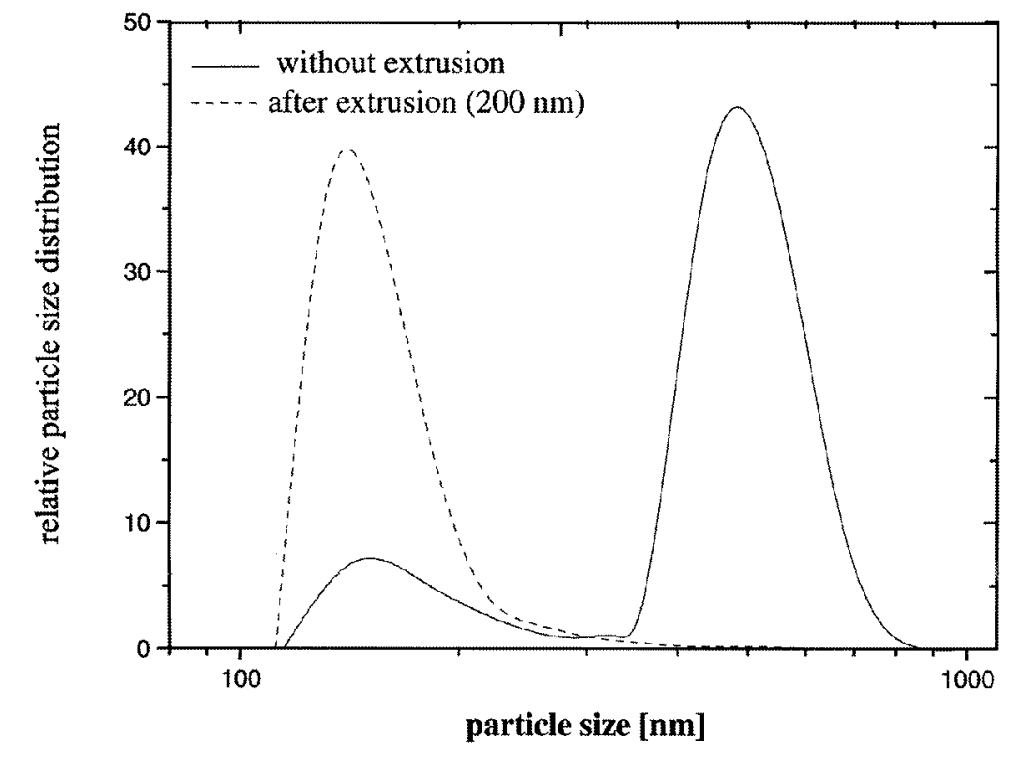

Figure 2. Light-scattering measurements of DMPC-reaction center protein liposomes formed after Bacillus sp.-catalyzed hydrolytic removal of OG. Particle size distribution of liposomes was determined directly after hydrolysis (solid line) and after extrusion ten times through a $200-\mathrm{nm}$ polycarbonate membrane (dotted line). 
wavelengths because of light scattering and the adsorption of incorporated protein (data not shown). With both sugar esters, $34 \%-39 \%$ of the protein initially added to the reaction mixture was incorporated into DMPC liposomes formed during lipase hydrolysis of OG, as calculated by measuring the absorbance of the proteoliposomes at $802 \mathrm{~nm}$.

\section{DISCUSSION}

We report here that synthetic sugar fatty esters such as $\mathrm{OG}$ and $\mathrm{OM}$ allow for the solubilization of the reaction center protein of $R$. sphaeroides in yields and purities comparable to LDAO (6). The advantage of using these compounds is that they can be removed by lipase-catalyzed hydrolysis and thus allow for a simplified purification scheme. Using this method, the reconstitution of the reaction center protein of $R$. sphaeroides into DMPC phospholipid vesicles could be achieved in yields greater than $30 \%$. Investigations are now underway to investigate the use of this method for the purification and reconstitution of other membrane proteins.

\section{ACKNOWLEDGMENTS}

Financial support by the NEDO (Tokyo, Japan) is gratefully acknowledged. Furthermore, we thank Novo Nordisk Co. (Bagsvaerd, Denmark), Roche Diagnostics (Penzberg, Germany), Asahi Chemicals (Tokyo, Japan) and Amano Pharmaceuticals Inc., (Nagoya, Japan) for gifts of various lipases. The help of Sandra Pisch-Heberle in editing the final version of this manuscript is gratefully appreciated.

\section{REFERENCES}

1.Cao, L., U.T. Bornscheuer and R.D. Schmid. 1996. Lipase-catalyzed solid phase synthesis of sugar esters. Fett/Lipid 98:332335.

2.Cao, L., T.T. Bornscheuer and R.D. Schmid. 1998. Lipase-catalyzed solid phase synthesis of sugar esters, IV: selectivity of lipases towards primary and secondary hydroxyl groups in carbohydrates. Biocatal. Biotransform. 16:249-257.

3.Cao, L., U.T. Bornscheuer and R.D. Schmid.
1999. Lipase-catalyzed solid phase synthesis of sugar esters. Influence of immobilization on productivity and stability of the enzyme. J. Mol. Catal. B: Enzymatic 6:279-285.

4.Cao, L., A. Fischer, U.T. Bornscheuer and R.D. Schmid. 1997. Lipase-catalyzed solid phase synthesis of sugar fatty acid esters. Biocatal. Biotransform. 14:269-283.

5.Crielaard, W., K.J. Hellingwerf and W.N. Konings. 1989. Reconstitution of electrochromically active pigment-protein complexes from Rhodobacter sphaeroides into liposomes. Biochim. Biophys. Acta 973:205-211.

6.Feher, G. and M.Y. Okamura. 1978. Chemical Compositions and Properties of Reaction Centers. Plenum Press, New York.

7.Gabellini, N., Z. Gao, D. Oesterhelt, G. Venturoli and B.A. Melandri. 1989. Reconstitution of cyclic electron transport and photophosphorylation by incorporation of the reaction center, cytochrome bc1 complex and ATP synthase from Rhodobacter capsulatus into ubiquinone-10/phospholipid vesicles. Biochim. Biophys. Acta 974:202-210.

8.Gast, P., P.W. Hemelrijk, J.V. Gorkom and A.J. Hoff. 1996. The association of different detergents with the photosynthetic reaction center protein of Rhodobacter sphaeroides R26 and the effects on its photochemistry. Eur. J. Biochem. 239:805-809.

9.Gray, K.A., J.W. Farchaus, J. Wachtveitl, J. Breton and D. Oesterhelt. 1990. Initial characterization of site-directed mutants of tyrosine M210 in the reaction centre of Rhodobacter sphaeroides. EMBO J. 9:2061-2070.

10.Hara, M., T. Ueno, T. Fujii, Q. Yang, Y. Asada and J. Miyake. 1997. Orientation of photosynthetic reaction center reconstituted in neutral and charged liposomes. Biosci. Biotech. Biochem. 9:1577-1579

11.Holloway, P.M. 1973. A simple procedure for removal of Triton X-100 from protein samples. Anal. Biochem. 53:304-308.

12.Knol, J., K. Sjollema and B. Poolman. 1998 Detergent-mediated reconstitution of membrane proteins. Biochemistry 37:1641016415.

13.Levy, D., A. Gulik, A. Bluzat and J.-L. Rigaud. 1992. Reconstitution of the sarcoplasmic reticulum Ca2+-ATPase: mechanisms of membrane protein insertion into liposomes during reconstitution procedures involving the use of detergent. Biochim. Biophys. Acta 1107:283-298.

14.Moser, C.C. and P.L. Dutton. 1988. Cytochrome $\mathrm{c}$ and $\mathrm{c} 2$ binding dynamics and electron transfer with photosynthetic reaction center protein and other integral membrane redox proteins. Biochemistry 27:2450-2461.

15.Paternostre, M.-T., M. Roux and J.-L. Rigaud. 1988. Mechanisms of membrane protein insertion into liposomes during reconstitution procedures involving the use of detergents. 1. Solubilization of large unilamellar liposomes (prepared by reverse-phase evaporation) by Triton X-100, octyl glucoside, and sodium cholate. Biochemistry 27:26682677.

16.Peters, H., C. Schmidt-Dannert and R.D. Schmid. 1997. The photoreaction center of Rhodobacter sphaeroides: a "biosensor protein" for the determination of photosystem-II herbicides? Mat. Sci. Eng. C4:227-232.

17.Rich, P.R. and P. Heathcote. 1983. Light-activated protein-motive force generation in lipid vesicles containing cytochrome b-c1 complex and bacterial reaction centres. Biochim. Biophys. Acta 725:332-340.

18.Rigaud, J.-L., B. Pitard and D. Levy. 1995. Reconstitution of membrane proteins into liposomes: application to energy-transducing membrane proteins. Biochim. Biophys. Acta 1231:223-246.

19.Römer-Lüthi, C.R., P. Ott and U. Brodbeck. 1980. Reconstitution of human erythrocyte membrane acetylcholinesterase in phospholipid vesicles. Biochim. Biophys. Acta 601:123-133.

20.Scotto, A.W., D. Goodwyn and D. Zakim. 1987. Reconstitution of membrane proteins: sequential incorporation of integral membrane proteins into preformed lipid bilayers. Biochemistry 26:833-839.

21.Sistrom, W.R. 1960. A requirement for sodium in the growth of Rhodopseudomonas spheroides. J. Gen. Microbiol. 22:778-785.

22.Straley, S.C., W.W. Parson, D.C. Mauzerall and R.K. Clayton. 1973. Pigment content and molar extinction coefficients of photochemical reaction centers from Rhodopseudomonas spheroides. Biochim. Biophys. Acta 305:597-609.

23.Wang, S., S. Lin, X. Lin, N.W. Woodbury and J.P. Allen. 1994. Comparative study of reaction centers from purple photosynthetic bacteria: Isolation and optical spectroscopy. Photosynth. Res. 42:203-215.

24.Weetal, H.H. 1976. Covalent coupling methods for in organic support material. Methods Enzymol. 44:134-148.

25.Wrigglesworth, J.M., M.S. Wooster, J. Elsden and H.-J. Danneel. 1987. Dynamics of proteoliposome formation. Intermediate states during detergent dialysis. Biochem. J. 246:737-744.

Received 25 June 1999; accepted 19 January 2000.

Address correspondence to:

Prof. Rolf D. Schmid

Institut für Technische Biochemie

Universität Stuttgart

Allmandring 31

D-70569 Stuttgart

Germany

Internet: rolf.d.schmid@rus.uni-stuttgart.de 